\title{
Assessment of Six E-Mail Encryption Solutions Using an Utility Value Analysis
}

\author{
D. Fischer, B. Markscheffel, K. Scherr \\ Technische Universität Ilmenau \\ Ilmenau, Germany
}

\begin{abstract}
E-mail is one of the most frequently used form of communication. Confidentiality, integrity and authenticity are often indispensable in e-mail communication, especially in business use. However, these security objectives can only be guaranteed with the help of additional encryption solutions. Today, there are a variety of client, gateway and software-asa-service solutions for e-mail encryption. Companies are faced with the challenge of finding the most suitable solution for them. Our research work presents findings from a utility value analysis which provides a comprehensive process for assessing and selecting an appropriate solution for securing e-mail traffic. We present the basic principles behind the utility value analysis and how it is used for the evaluation process of e-mail encryption solutions. In addition, we document how our methodology was applied in a practice-based project to make a selection decision between six existing e-mail encryption solutions.
\end{abstract}

\section{Introduction}

Since Ray Tomlinson's first e-mail in 1971 [1] this asynchronous communication issue has evolved to a mass phenomenon with strong effects to all personal and business spheres. The total number of business and consumer e-mails sent and received per day will reach in 2017269 billion and is expected to continue to grow to 319.6 billion by the end of 2021 [2]. Especially the impact in business communication is enormous. But in this case, it is essential to ensure that e-mail content remains confidential between the sender and the receiver, especially if the e-mail includes sensitive information like HR data, payment related data, financial records or intellectual property [3]. The main solution is encrypting the e-mail. The reality in practice very often looks quite different. According to a study of Ponemon Institute, $61 \%$ of the respondents said that employees sent sensitive data unencrypted through e-mail [4]. Another survey conducted by Osterman Research indicates that e-mail encryption is used "extensively" by only 40 percent of organizations [5]. On the other hand, there is a wide world of e-mail encryption solutions available [6]. This variety of solutions shows that the main problem has changed from looking for a method of e-mail encryption to selecting the most suitable encryption solution.

The objective of our work is to derive a methodology for the selection of a suitable e-mail encryption solution based on the utility value approach. Furthermore, the applicability of the methodology should be presented in a practice-based project.

The paper is organized as follows: In the next section we define important terms in the context of the paper and provide a summary of related work. In section 3 we give an overview of the utility value analysis and describe how it can be used to assess and select an e-mail encryption solution. Finally, we conclude the paper with a brief summary and an outlook of future research.

\section{Related work}

E-mail encryption solutions in this paper are all products that use cryptographic methods to improve the confidentiality, integrity or authenticity of e-mail communications [7, 8]. Based on [9] we distinguish between three different types of products:

- client solutions: cryptographic methods are used directly on the clients of the senders and receivers of e-mails,

- gateway (or server-based) solutions: central, organization-internal systems provide the functions for securing e-mail communication,

- and software-as-a-service (or cloud-based) solutions: organization-external providers enable encryption, decryption, signing and verification of e-mails.

There are a large number of alternatives for all three types of e-mail encryption solutions. Schneider et al. identify a total of 89 e-mail encryption solutions as part of a worldwide survey on encryption hardware and software products [6]. Various market studies 
assume that the offered amount of solutions will continue to grow and predict a strong growth of the global e-mail encryption market over the next few years $[10,11]$.

There is certainly literature that contains criteria and recommendations for selecting e-mail encryption solutions. The National Institute of Standards and Technology (NIST) publishes guidelines on the security of electronic messages to help organizations develop, set up and operate their e-mail systems [12]. Requirements and comparison criteria for e-mail encryption solutions can be derived from this, for example. Moecke and Volkamer identify evaluation criteria covering security, usability, and interoperability aspects of e-mail security, and to apply them to existing solutions [13]. Fox describes requirements for e-mail security solutions, specifies important evaluation criteria and gives an overview of the most important standards for e-mail security [14]. On this basis he develops exemplary decision-making aids and makes recommendations for the selection of suitable solutions. Without evaluating specific products, other authors also compare the different types of e-mail encryption solutions (client, gateway, SaaS), discuss their advantages and disadvantages and derive typical applications and recommendations from them [9].

A systematic and yet flexible methodology for selecting e-mail encryption solutions is currently missing.

\section{Methodical approach and results}

We use the utility value analysis (UVA) as a basic methodical guideline for structuring and justifying the selection process. The UVA provides a set of complex action alternatives with the purpose of arranging the elements of this set according to the decision-maker's preferences regarding a multi-dimensional target system [15].

Generally, the UVA is structured in following five steps:

1. Define target system

2. Determine target returns

3. Determine target values

4. Determine weighting of target criteria

5. Perform value synthesis [16].

In the following sections we will explain, how we had applied this methodology to support the selection process for an appropriate encryption solution in a practice-based project. In this project, we evaluated six solutions (two client, two gateway, and two software-as-a-service solutions) that were preselected by our practice partner. The selection was oriented on current comparison tests of practical IT-journals [17, 18]. Following six e-mail encryption solutions were selected:
- $\quad$ Mailvelope v1.3.6,

- Gpg4win v2.3.1,

- SEPPMail Gateway 500,

- Z1 SecureMail Gateway,

- Mailbox.org,

- StartMail.com.

The approach, selecting the software solutions by referring to practically relevant IT-journals ensures that the considered alternatives are current and practically relevant.

\subsection{Define target system}

There is no generally applicable approach for defining the target system. However, it makes sense to aim for a minimization of the targets with simultaneous completeness and redundancy free [8]. We performed a literature analysis to identify the main targets. We queried ACM Digital Library, AISeL, EBSCOhost, IEEE Xplore, ScienceDirect, Springer-Link, Google Scholar and a previous selected set of specialized journals with the following terms: "e-mail, encryption, software, solution" combined with "criteria, compar*, evaluation, select*, choose". As a result, we were able to compile the functional and non-functional targets shown in Table 1.

Table 1. Compiled Target System

\begin{tabular}{|l|l|}
\hline Functional Targets & Non-Functional Targets \\
\hline $\begin{array}{l}\text { High confidentiality of } \\
\text { message exchange (VN) }\end{array}$ & Low installation effort (IA) \\
\hline $\begin{array}{l}\text { High integrity assurance } \\
\text { during message exchange (IN) }\end{array}$ & Low acquisition costs (AK) \\
\hline $\begin{array}{l}\text { High identity assurance of the } \\
\text { communication partners (IK) }\end{array}$ & Low operating costs (BK) \\
\hline Ensure high availability (VB) & Ease of operation (EB) \\
\hline Large scope of services (LU) & Good support (SU) \\
\hline & $\begin{array}{l}\text { High trustworthiness of the } \\
\text { manufacturer/provider (HV) }\end{array}$ \\
\hline & $\begin{array}{l}\text { High system/product maturity } \\
\text { (SR) }\end{array}$ \\
\hline & Good integrability (IB) \\
\hline
\end{tabular}

In order to operationalize the target system, we defined suitable target criteria for all targets, with the help of the previous selected literature. For this purpose, the targets were broken down into subtargets (target criteria). Table 2 shows the result of this top-down procedure.

For each target criterion, we defined possible criterion values and determined how they can contribute to the achievement of the target. This is briefly outlined below using the target criteria VN2 and VN3 as an example. 
The target criterion VN2 "Place of encryption" states, where or rather on which system the encryption and decryption of e-mail takes place. We distinguish three possible criteria values: client, gateway and external.

Table 2. Target criteria

\begin{tabular}{|c|c|}
\hline \multicolumn{2}{|c|}{ Targets / Target criteria } \\
\hline \multicolumn{2}{|c|}{ High confidentiality of message exchange (VN) } \\
\hline VN1 & Content encryption procedure \\
\hline VN2 & Place of encryption \\
\hline VN3 & Encrypting e-mail attachments \\
\hline VN4 & Transport encryption procedure \\
\hline VN5 & Enhancements to transport encryption \\
\hline \multicolumn{2}{|r|}{ High integrity assurance during message exchange (IN) } \\
\hline IN1 & Signature creation and verification possible \\
\hline \multicolumn{2}{|r|}{ High identity assurance of the communication partners (IK) } \\
\hline IK1 & Creation of certificates possible \\
\hline IK2 & Signature creation and verification possible \\
\hline \multicolumn{2}{|c|}{ Ensure high availability (VB) } \\
\hline VB1 & Dependence on the manufacturer/provider \\
\hline \multicolumn{2}{|c|}{ Large scope of services (LU) } \\
\hline LU1 & Spam and malware filtering \\
\hline LU2 & $\begin{array}{l}\text { Secure communication with non-PGP and -S/MIME } \\
\text { users }\end{array}$ \\
\hline LU3 & Data Loss Prevention (DLP) \\
\hline LU4 & Sending large files \\
\hline LU5 & Subsequent encryption of incoming e-mail \\
\hline \multicolumn{2}{|c|}{ Low installation effort (IA) } \\
\hline IA1 & Creation of key pairs by the end user \\
\hline IA2 & $\begin{array}{l}\text { Certification of the public keys for each end user, if } \\
\text { necessary }\end{array}$ \\
\hline IA3 & $\begin{array}{l}\text { Publishing of the public keys to all communication } \\
\text { partners by end users }\end{array}$ \\
\hline IA4 & $\begin{array}{l}\text { Collection of public keys from all communication } \\
\text { partners by end users }\end{array}$ \\
\hline IA5 & $\begin{array}{l}\text { Installation and configuration of software on all client } \\
\text { PCs, if necessary }\end{array}$ \\
\hline IA6 & $\begin{array}{l}\text { Installation and configuration of central software, if } \\
\text { necessary }\end{array}$ \\
\hline \multicolumn{2}{|r|}{ Low acquisition costs (AK) } \\
\hline AK1 & One-time costs \\
\hline \multicolumn{2}{|c|}{ Low operating costs (BK) } \\
\hline BK1 & Regular (monthly) costs \\
\hline \multicolumn{2}{|c|}{ Ease of operation (EB) } \\
\hline EB1 & $\begin{array}{l}\text { Additional user actions required when sending / } \\
\text { receiving }\end{array}$ \\
\hline EB2 & Knowledge of encryption and signing required \\
\hline \multicolumn{2}{|c|}{ Good support (SU) } \\
\hline SU1 & $\begin{array}{l}\text { Help function on homepage, e. g. FAQ, documentation, } \\
\text { interactive e-mail support }\end{array}$ \\
\hline SU2 & Hotline \\
\hline
\end{tabular}

\begin{tabular}{|l|l|}
\hline SU3 & On-site service \\
\hline High trustworthiness of the manufacturer/provider (HV) \\
\hline HV1 & Data protection, legal regulations in the country of origin \\
\hline HV2 & Awards \\
\hline HV3 & Known vulnerabilities, backdoors \\
\hline HV4 & Source code viewable \\
\hline HV5 & $\begin{array}{l}\text { Experience in the fields of encryption, secure digital } \\
\text { communication, etc. }\end{array}$ \\
\hline HV6 & References \\
\hline High system/product maturity (SR) \\
\hline SR1 & Period since the first product generation appeared \\
\hline Good integrability (IB) \\
\hline IB1 & $\begin{array}{l}\text { Secure e-mail communication from mobile devices } \\
\text { possible }\end{array}$ \\
\hline IB2 & $\begin{array}{l}\text { Availability/compatibility with desktop operating } \\
\text { systems }\end{array}$ \\
\hline IB3 & Compatibility with e-mail clients \\
\hline
\end{tabular}

The confidentiality of message exchange is even better, the closer the content encryption/ decryption process is located to the sender and receiver systems. The highest level of target achievement is possible if encryption or decryption takes place directly on the client systems of the communication partners and emails are thus transmitted in encrypted form on the entire transmission path (end-to-end). Encryption using in-house gateways at least ensures that the emails are encrypted from or to the company boundary. It is assumed that this is less confidential than end-toend encryption. If the encryption/decryption is carried out by an external service provider, a further reduction in confidentiality can be assumed. The target criterion VN3 "Encryption of e-mail attachments" can be used to check whether only the e-mail messages themselves or their attachments are encrypted. Greater confidentiality of message exchange can be achieved if both e-mail messages and attachments are transmitted in encrypted form.

\subsection{Determine target returns}

In the second step, for each alternative (evaluated e-mail encryption solutions) the target returns are determined for each target criterion.

For this, we analysed the datasheets, product descriptions, whitepapers, manuals and similar documents. This approach ensures, that the target returns are compiled objective and are not attached by the user's subjective cognition. In case that the target returns cannot be determined this way, we contacted or interviewed the manufacturer's support.

Table 3 shows a cutout of the complex matrix for the first target and its target criteria. The complete table with the determination of all target criteria for all six analysed solutions can be found at Appendix 1. 
Table 3. Cutout of the Target Returns Matrix

\begin{tabular}{|c|c|c|c|c|}
\hline \multicolumn{5}{|c|}{$\begin{array}{l}\text { Target: High confidentiality of message exchange (VN) } \\
\text { Target criteria: } \\
\text { Content encryption procedure (VN1) } \\
\text { Place of encryption (VN2) } \\
\text { Encrypting e-mail attachments (VN3) } \\
\text { Transport encryption procedure (VN4) } \\
\text { Enhancements to Transport Encryption (VN5) }\end{array}$} \\
\hline & \multicolumn{4}{|c|}{ Alternative Solutions } \\
\hline & Mailvelope & $\begin{array}{l}\text { Z1 SecureMail } \\
\text { Gateway }\end{array}$ & StartMail.com & .. \\
\hline VN1 & OpenPGP & $\begin{array}{l}\text { OpenPGP, } \\
\text { S/MIME }\end{array}$ & OpenPGP & \\
\hline VN2 & Client-PC & $\begin{array}{l}\text { Gateway } \\
\text { (intern) }\end{array}$ & $\begin{array}{c}\text { StartMail } \\
\text { Server (extern) }\end{array}$ & \\
\hline VN3 & No & Yes & No & \\
\hline VN4 & TLS 1.2 & TLS 1.2 & TLS 1.2 & \\
\hline VN5 & $\begin{array}{l}\text { PFS, DANE } \\
\text { via add-ons }\end{array}$ & PFS & PFS & \\
\hline$\cdots$ & & & & \\
\hline
\end{tabular}

\subsection{Determine target values}

The relatively freely formulated alphanumeric target returns cannot be compared properly with each other. Therefore, they are transformed into nondimensional quantities and represented in so-called target values. In our case, the target returns are transformed into target values according to a fivelevel nominal scale ( 1 -insufficient ... 5-very good). In Table 4 we show the same matrix cutout with its target values. The full target value matrix can also be found at Appendix 2.

Table 4. Cutout of the Target Value Matrix

\begin{tabular}{|l|c|c|c|c|}
\hline \multirow{2}{*}{} & \multicolumn{4}{|c|}{ Alternative Solutions } \\
\cline { 2 - 5 } & Mailvelope & $\begin{array}{c}\text { Z1 SecureMail } \\
\text { Gateway }\end{array}$ & StartMail.com & $\ldots$ \\
\hline VN1 & 3 & 5 & 3 & \\
\hline VN2 & 5 & 4 & 1 & \\
\hline VN3 & 1 & 5 & 1 & \\
\hline VN4 & 5 & 5 & 5 & \\
\hline VN5 & 5 & 4 & 4 & \\
\hline$\ldots$ & \multicolumn{5}{|l}{} \\
\hline
\end{tabular}

\subsection{Determine weighting of target criteria}

In order to take into account, the individual application context of the encryption solution, which expresses itself through individual requirements, a weighting of the target criteria is necessary. For example, acquisition costs can have a different weighting depending on the amount of financial resources allocated. In our practice-based project, weights were used on the target level and not on the target criteria level. Furthermore, these weights were collected through a survey where security and IT specialists were interviewed with the help of questionnaires. The weights of the targets have been passed on to their criteria. Table 5 shows the target weights for our practice-based project.

Table 5. Average Weighted targets

\begin{tabular}{|c|c|c|c|c|c|c|c|}
\hline \multicolumn{8}{|c|}{ Functional Targets } \\
\hline VN & IN & $\mathrm{IK}$ & VB & LU & & & \\
\hline 3.8 & 3.6 & 3.8 & 3.2 & 2.4 & & & \\
\hline \multicolumn{8}{|c|}{ Non-Functional Targets } \\
\hline IA & $\mathrm{AK}$ & $\mathrm{BK}$ & $\mathrm{EB}$ & $\mathrm{SU}$ & $\mathrm{HV}$ & SR & IB \\
\hline 2.6 & 3.0 & 3.4 & 2.8 & 2.8 & 3.2 & 2.6 & 3.6 \\
\hline
\end{tabular}

\subsection{Perform value synthesis}

In the final step of the utility value analysis the target values are multiplied with the weights and summed up to the so-called total benefit for each alternative. A detailed documentation of the calculation of the total benefits can be found in Appendix 3. According to the principle of utility value analysis, the alternative is considered to be the "best" with the greatest overall benefit. In Figure 1 the final results are shown for our set of alternative solutions.

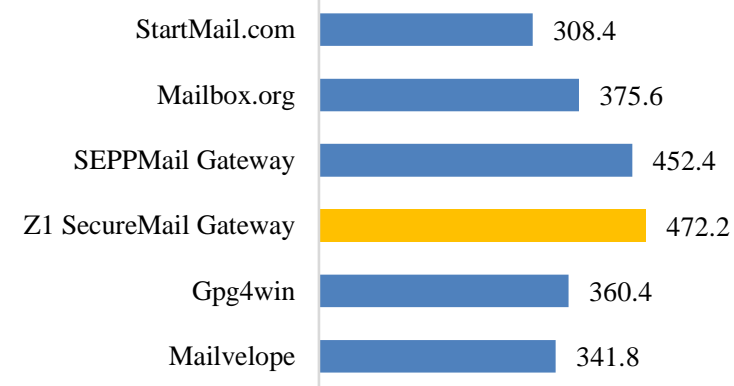

Figure 1. Total benefits of the alternative solutions

\section{Conclusion}

In this paper, we have applied the utility value analysis (UVA) as a decision support concept to the selection process of encryption solutions for e-mail communication. In our practice-oriented project, Z1 SecureMail Gateway from Zertificon is the solution with the greatest overall benefit. We were able to show that the selection process is made much more transparent by the UVA in particular because the individual requirements of users can be taken into account directly in the selection process by weighting the target criteria.

In order to regard the individual requirements in the selecting process even more it could be useful to perform the UVA twice. By the first UVA, the product 
category (client, gateway, cloud-based) is selected. By the following second UVA, the concrete product within the category is selected. Such a cascaded approach furthermore has the advantage, that more category-specific criteria could be regarded within the second UVA.

\section{References}

[1] T. Campell, The first email message, https://www.cs. umd.edu/class/spring2002/cmsc434-0101/MUIseum/applications/firstemail.html (Accessed: 2017-09-11).

[2] The Radicati Group, Email Statistics Report 2017-2021, Feb 2017, https://www.radicati.com/wp/wp-content/uploads/2017/01/Email-Statistics-Report-2017-2021-ExecutiveSummary.pdf (Accessed: 2017-09-11).

[3] Thales, Global encryption trends 2017, Apr 2017, https://gets.thalesesecurity.com/pdf/ponemon-globalencryption-trends-study-infographic.pdf (Accessed: 201607-05).

[4] Pnomenon, The state of email encryption, 2017, https://www.laninfotech.com/email-security (Accessed: 2017-07-05).

[5] Osterman Research, Enterprise Encryption and Authentication Usage, 2016, https://www.echoworx. com/assets/Enterprise-Encryption-and-Authentication-Usage-A-Survey-Report.pdf (Accessed: 2017-09-05).

[6] B. Schneier, K. Seidell, and S. Vijayakumar, A Worldwide Survey of Encryption Products, 2016, https://www.schneier.com/academic/paperfiles/worldwidesurvey-of-encryption-products.pdf (Accessed: 2017-0926).

[7] B. Schneier, Secrets \& Lies, dpunkt, Heidelberg, 2004.

[8] B. Schneier, E-mail Security. How to Keep Your Electronic Messages Private, John Wiley \& Sons, New York, 1995.

[9] DsN - Deutschland sicher im Netz, Verschlüsselung von E-Mails - Leitfaden zur E-Mail-Sicherheit für Unternehmen, Berlin, 2015, https://www.sicher-imnetz.de/sites/default/files/download/leitfaden-e-mailverschluesselung.pdf (Accessed: 2017-08-07).

[10] Technavio, Global E-mail Encryption Market 20172021, Dec 2016, https://www.technavio.com/report/ global-it-security-global-e-mail-encryption-market-20172021 (Accessed: 2017-10-10).

[11] MarketsandMarkets, Email Encryption Market by Deployment Type, Industry Vertical, and Region - Global Forecast to 2020, Nov 2015, http://www.marketsandmarkekets.com/Market-Reports/email-encryption-market-182623 205.html (Accessed: 2017-05-15).

[12] National Institute of Standards and Technology (NIST), Guidelines on Electronic Mail Security, SP 800-45 Version 2, Feb 2007.
[13] C. Moecke, M. Volkamer, "Usable secure E-Mail communications - criteria and evaluation of existing approaches," in Information Management \& Computer Security, vol. 21, no. 1, 2013, pp. 41-52.

[14] D. Fox, "E-Mail-Sicherheit: Kriterien, Standards und Lösungen," in Datenschutz und Datensicherheit, vol. 25, no. 8, 2001, pp. 452-458.

[15] C. Zangemeister, Nutzwertanalyse in der Systemtechnik, Books on Demand, Norderstedt, 2014.

[16] L. Heinrich, R. Riedl, D. Stelzer, Informationsmanagement: Grundlagen, Aufgaben, Methoden, Oldenbourg, München, 2014.

[17] H. Bleich, „Abhörsicher Mail-Services im Test,“ in Überwachung abwehren, c't wissen Sonderheft, 09/2015, pp. 66-91.

[18] T. Bär, "Tests: SEPPmail VM Secure E-Mail Gateway 500“, in IT-Administrator, 02/2015, pp. 20-26. 


\section{Appendix 1: Target Returns Matrix}

\begin{tabular}{|c|c|c|c|c|c|c|}
\hline \multirow{2}{*}{ Targets / Target criteria } & \multicolumn{6}{|c|}{ Alternative Solutions } \\
\hline & Mailvelope & Z1 SecureMail Gateway & StartMail.com & Gpg4win & SEPPMail Gateway & Mailbox.org \\
\hline \multicolumn{7}{|l|}{ High confidentiality of message exchange (VN) } \\
\hline VN1: Content encryption procedure & OpenPGP & OpenPGP, S/MIME & OpenPGP & OpenPGP, S/MIME & OpenPGP, S/MIME & OpenPGP \\
\hline VN2: Place of encryption & Client-PC & Gateway (intern) & $\begin{array}{l}\text { StartMail Server } \\
\text { (extern) }\end{array}$ & Client-PC & Gateway (intern) & Mailbox.org Server (extern) \\
\hline VN3: Encrypting e-mail attachments & No & Yes & No & Yes & Yes & Yes \\
\hline VN4: Transport encryption procedure & TLS 1.2 & TLS 1.2 & TLS 1.2 & TLS 1.2 & TLS 1.2 & TLS 1.2 \\
\hline $\begin{array}{l}\text { VN5: Enhancements to transport } \\
\text { encryption }\end{array}$ & $\begin{array}{l}\text { PFS, DANE via add- } \\
\text { ons (firefox/chrom) }\end{array}$ & PFS & PFS & PFS & $\begin{array}{c}\text { PFS } \\
\text { (in the pipeline DANE) } \\
\end{array}$ & PFS, DANE \\
\hline \multicolumn{7}{|c|}{ High integrity assurance during message exchange (IN) } \\
\hline $\begin{array}{l}\text { IN1: Signature creation and } \\
\text { verification possible }\end{array}$ & Yes & $\begin{array}{l}\text { Yes (automatically or } \\
\text { manually from end user) }\end{array}$ & Yes & Yes & \begin{tabular}{|c|} 
Yes (automatically or \\
manually from end user)
\end{tabular} & Yes \\
\hline \multicolumn{7}{|c|}{ High identity assurance of the communication partners (IK) } \\
\hline IK1: Creation of certificates possible & No & Yes & No & Yes & Yes & No \\
\hline $\begin{array}{l}\text { IK2: Signature creation and } \\
\text { verification possible }\end{array}$ & Yes & $\begin{array}{l}\text { Yes (automatically or } \\
\text { manually from end user) }\end{array}$ & Yes & Yes & $\begin{array}{c}\text { Yes (automatically or } \\
\text { manually from end user) }\end{array}$ & Yes \\
\hline \multicolumn{7}{|l|}{ Ensure high availability (VB) } \\
\hline $\begin{array}{l}\text { VB1: Dependence on the } \\
\text { manufacturer/provider }\end{array}$ & $\begin{array}{l}\text { Software and add-on } \\
\text { must be available for } \\
\text { download }\end{array}$ & $\begin{array}{c}\text { Gateway must be available } \\
\text { (hardware or software, } \\
\text { VM) }\end{array}$ & $\begin{array}{l}\text { Service must be } \\
\text { available }\end{array}$ & \begin{tabular}{|c|}
$\begin{array}{c}\text { Software package must } \\
\text { be available for } \\
\text { download }\end{array}$ \\
\end{tabular} & \begin{tabular}{|c|} 
Gateway must be \\
available (hardware or \\
software, VM)
\end{tabular} & Service must be available \\
\hline \multicolumn{7}{|l|}{ Large scope of services (LU) } \\
\hline LU1: Spam and malware filtering & No & Yes & Yes & No & Yes & Yes \\
\hline $\begin{array}{l}\text { LU2: Secure communication with } \\
\text { non-PGP and -S/MIME users }\end{array}$ & No & Yes & Yes & No & Yes & Yes \\
\hline LU3: Data Loss Prevention (DLP) & No & Yes & No & No & No & No \\
\hline LU4: Sending large files & No & Yes & No & No & Yes & No \\
\hline $\begin{array}{l}\text { LU5: Subsequent encryption of } \\
\text { incoming e-mail }\end{array}$ & No & No & No & No & No & Yes \\
\hline \multicolumn{7}{|l|}{ Low installation effort (IA) } \\
\hline $\begin{array}{l}\text { IA1: Creation of key pairs by the end } \\
\text { user }\end{array}$ & Yes & No & Yes & Yes & No & Yes \\
\hline $\begin{array}{l}\text { IA2: Certification of the public keys } \\
\text { for each end user, if necessary }\end{array}$ & No & Only when using S/MIME & No & $\begin{array}{l}\text { Only when using } \\
\text { S/MIME }\end{array}$ & $\begin{array}{l}\text { Only when using } \\
\text { S/MIME }\end{array}$ & No \\
\hline $\begin{array}{l}\text { IA3: Publishing of the public keys to } \\
\text { all communication partners by end } \\
\text { users }\end{array}$ & Yes & Yes & $\begin{array}{c}\text { Yes, but automatic } \\
\text { signature creation is } \\
\text { not possible }\end{array}$ & Yes & Yes & Yes \\
\hline $\begin{array}{l}\text { IA4: Collection of public keys from } \\
\text { all communication partners by end } \\
\text { users }\end{array}$ & Yes & $\begin{array}{l}\text { Yes, but only attached } \\
\text { signatures are } \\
\text { automatically read and } \\
\text { saved } \\
\end{array}$ & \begin{tabular}{|c|} 
Yes, but only \\
automatically if the \\
recipient is also a \\
user of StartMail \\
\end{tabular} & Yes & \begin{tabular}{|c|}
$\begin{array}{c}\text { Yes, but only attached } \\
\text { signatures are } \\
\text { automatically read and } \\
\text { saved }\end{array}$ \\
\end{tabular} & $\begin{array}{c}\text { Yes, but only automatically if } \\
\text { the recipient is also a user of } \\
\text { mailbox.org }\end{array}$ \\
\hline $\begin{array}{l}\text { IA5: Installation and configuration of } \\
\text { software on all client PCs, if } \\
\text { necessary }\end{array}$ & Yes & No & No & Yes & No & No \\
\hline $\begin{array}{l}\text { IA6: Installation and configuration of } \\
\text { central software, if necessary }\end{array}$ & No & Yes & No & No & Yes & No \\
\hline \multicolumn{7}{|l|}{ Low acquisition costs $(\mathrm{AK})$} \\
\hline AK1: One-time costs & No & $\begin{array}{c}\begin{array}{c}\text { Yes, depending on number } \\
\text { of employees and scope of } \\
\text { functions }\end{array} \\
\end{array}$ & No & No & $\begin{array}{c}\text { Yes, depending on } \\
\text { number of employees } \\
\text { and scope of functions }\end{array}$ & No \\
\hline \multicolumn{7}{|l|}{ Low operating costs (BK) } \\
\hline BK1: Regular (monthly) costs & No & - & Yes & No & - & Yes \\
\hline \multicolumn{7}{|l|}{ Ease of operation (EB) } \\
\hline $\begin{array}{l}\text { EB1: Additional user actions required } \\
\text { when sending / receiving }\end{array}$ & Yes & $\begin{array}{l}\text { Depending on the settings } \\
\text { at the gateway, user } \\
\text { interaction can be } \\
\text { completely avoided }\end{array}$ & $\begin{array}{l}\text { Yes, optional it is } \\
\text { possible that every } \\
\text { outgoing e-mail is } \\
\text { encrypted } \\
\text { automatically }\end{array}$ & \begin{tabular}{|c|} 
Yes, sometimes very \\
cumbersome operation, \\
e. g. sending, selecting \\
certificates and \\
encrypting attachments \\
\end{tabular} & $\begin{array}{l}\text { Depending on the } \\
\text { settings at the gateway, } \\
\text { user interaction can be } \\
\text { completely avoided }\end{array}$ & $\begin{array}{l}\text { Yes, optional it is possible } \\
\text { that every outgoing e-mail is } \\
\text { encrypted automatically }\end{array}$ \\
\hline $\begin{array}{l}\text { EB2: Knowledge of encryption and } \\
\text { signing required }\end{array}$ & Yes & $\begin{array}{l}\text { Not necessarily (if the } \\
\text { gateway is configured } \\
\text { accordingly) }\end{array}$ & Yes & Yes & $\begin{array}{l}\text { Not necessarily (if the } \\
\text { gateway is configured } \\
\text { accordingly) }\end{array}$ & Yes \\
\hline \multicolumn{7}{|l|}{ Good support (SU) } \\
\hline $\begin{array}{l}\text { SU1: Help function on homepage, } \\
\text { e. g. FAQ, documentation, interactive } \\
\text { e-mail support }\end{array}$ & $\begin{array}{c}\text { Yes } \\
\text { (FAQ, user } \\
\text { documentation) }\end{array}$ & Yes & $\begin{array}{c}\text { Yes } \\
\text { (FAQ, e-mail } \\
\text { support) }\end{array}$ & $\begin{array}{l}\text { Yes (multilingual, } \\
\text { e-mail support, very } \\
\text { detailed user } \\
\text { documentation) } \\
\end{array}$ & Yes & $\begin{array}{c}\text { Yes } \\
\text { (FAQ, web forum, } \\
\text { e-mail support) }\end{array}$ \\
\hline SU2: Hotline & No & Yes & No & No & Yes & No \\
\hline SU3: On-site service & No & $\begin{array}{l}\text { Yes, initial start-up by } \\
\text { Zertificon possible }\end{array}$ & No & No & $\begin{array}{l}\text { Yes, initial start-up by } \\
\text { SEPPMail possible }\end{array}$ & No \\
\hline \multicolumn{7}{|c|}{ High trustworthiness of the manufacturer/provider (HV) } \\
\hline $\begin{array}{l}\text { HV1: Data protection, legal } \\
\text { regulations in the country of origin }\end{array}$ & Germany & Germany & Netherlands & Sweden/Germany & Switzerland & Germany \\
\hline HV2: Awards & No & $\begin{array}{c}\text { Product of the year 2002 } \\
\text { (Internet World magazine) }\end{array}$ & No & No & No & $\begin{array}{c}\text { Test winner of } \\
\text { Stiftung Warentest } \\
\text { (Feb 2016) }\end{array}$ \\
\hline $\begin{array}{l}\text { HV3: Known vulnerabilities, } \\
\text { backdoors }\end{array}$ & No & No & No & No & No & No \\
\hline HV4: Source code viewable & Yes & No & No & Yes & No & Yes, partly (OX Guard) \\
\hline $\begin{array}{l}\text { HV5: Experience in the fields of } \\
\text { encryption, secure digital } \\
\text { communication, etc. }\end{array}$ & approx. 4 years & approx. 15 years & approx. 9 years & approx. 10 years & approx. 15 years & approx. 25 years \\
\hline HV6: References & $\begin{array}{l}\text { Use of certified DE- } \\
\text { Mail providers }\end{array}$ & $\begin{array}{c}\text { e.g. Allianz, IBM, Stiftung } \\
\text { Warentest, Deutscher } \\
\text { Sparkassen- und } \\
\text { Giroverband }\end{array}$ & - & - & $\begin{array}{l}\text { e.g. ING DiBa, EON, } \\
\text { KPMG }\end{array}$ & - \\
\hline \multicolumn{7}{|l|}{ High system/product maturity (SR) } \\
\hline $\begin{array}{l}\text { SR1: Period since the first product } \\
\text { generation appeared }\end{array}$ & approx. 4 years & approx. 10 years & approx. 2 years & approx. 10 years & approx. 14 years & approx. 12 years \\
\hline \multicolumn{7}{|l|}{ Good integrability (IB) } \\
\hline $\begin{array}{l}\text { IB1: Secure e-mail communication } \\
\text { from mobile devices possible }\end{array}$ & $\begin{array}{l}\text { Yes, but only via the } \\
\text { apps of WEB.DE or } \\
\text { GMX }\end{array}$ & No & No & No & No & No \\
\hline $\begin{array}{l}\text { IB2: Availability/compatibility with } \\
\text { desktop operating systems }\end{array}$ & \begin{tabular}{|l} 
Microsoft Windows 7- \\
10, Mac10.6 or higher, \\
Linux Debian, Ubuntu, \\
Fedora, OpenSuse \\
\end{tabular} & $\begin{array}{l}\text { Independent of desktop OS } \\
\text { (as embedded in the SMTP } \\
\text { stream) }\end{array}$ & $\begin{array}{l}\text { Microsoft Windows, } \\
\text { Mac, Linux }\end{array}$ & \begin{tabular}{|c|} 
Only Microsoft \\
Windows OS (XP...10)
\end{tabular} & $\begin{array}{l}\text { Independent of desktop } \\
\text { OS (as embedded in the } \\
\text { SMTP stream) }\end{array}$ & $\begin{array}{l}\text { Microsoft Windows, Mac, } \\
\text { Linux }\end{array}$ \\
\hline IB3: Compatibility with e-mail clients & Only web mailer & $\begin{array}{c}\text { All clients, } \\
\text { no restrictions }\end{array}$ & $\begin{array}{c}\text { All clients, } \\
\text { no restrictions }\end{array}$ & $\begin{array}{l}\text { Microsoft Outlook } \\
\text { (Plug-in) }\end{array}$ & $\begin{array}{c}\text { All clients, } \\
\text { no restrictions }\end{array}$ & $\begin{array}{c}\text { All clients, } \\
\text { no restrictions }\end{array}$ \\
\hline
\end{tabular}




\section{Appendix 2: Target Value Matrix}

\begin{tabular}{|c|c|c|c|c|c|c|c|}
\hline \multirow[b]{2}{*}{ Targets / Target criteria } & \multicolumn{6}{|c|}{ Alternative Solutions } & \multirow{2}{*}{$\begin{array}{l}\text { Notes on transformation of } \\
\text { target returns to target values }\end{array}$} \\
\hline & Mailvelope & $\begin{array}{l}\text { Z1 SecureMail } \\
\text { Gateway }\end{array}$ & StartMail.com & Gpg4win & $\begin{array}{l}\text { SEPPMail } \\
\text { Gateway }\end{array}$ & Mailbox.org & \\
\hline \multicolumn{8}{|l|}{\begin{tabular}{|l} 
High confidentiality of message exchange (VN) \\
\end{tabular}} \\
\hline VN1: Content encryption procedure & 3 & 5 & 3 & 5 & 5 & 3 & $\begin{array}{l}\text { Best case S/MIME and PGP, then only one of the } \\
\text { procedures; No content encryption would be the } \\
\text { worst-case scenario. }\end{array}$ \\
\hline VN2: Place of encryption & 5 & 4 & 1 & 5 & 4 & 1 & Better, the closer to the client PC. \\
\hline VN3: Encrypting e-mail attachments & 1 & 5 & 1 & 5 & 5 & 5 & Best case: Yes \\
\hline VN4: Transport encryption procedure & 5 & 5 & 5 & 5 & 5 & 5 & Best case: TLS 1.2 \\
\hline $\begin{array}{l}\text { VN5: Enhancements to transport } \\
\text { encryption }\end{array}$ & 5 & 4 & 4 & 4 & 4 & 5 & The more extensions, the better it is. \\
\hline \multicolumn{8}{|c|}{ High integrity assurance during message exchange (IN) } \\
\hline $\begin{array}{l}\text { IN1: Signature creation and } \\
\text { verification possible }\end{array}$ & 5 & 5 & 5 & 5 & 5 & 5 & Best case: Yes \\
\hline \multicolumn{8}{|c|}{ High identity assurance of the communication partners (IK) } \\
\hline IK1: Creation of certificates possible & 1 & 5 & 1 & 5 & 5 & 1 & Best case: Yes \\
\hline $\begin{array}{l}\text { IK2: Signature creation and } \\
\text { verification possible }\end{array}$ & 5 & 5 & 5 & 5 & 5 & 5 & Best case: Yes \\
\hline \multicolumn{8}{|l|}{ Ensure high availability (VB) } \\
\hline $\begin{array}{l}\text { VB1: Dependence on the } \\
\text { manufacturer/provider }\end{array}$ & 3 & 3 & 1 & 3 & 3 & 1 & The worst performers are service providers. \\
\hline \multicolumn{8}{|l|}{ Large scope of services (LU) } \\
\hline LU1: Spam and malware filtering & 1 & 5 & 5 & 1 & 5 & 5 & Best case: Yes \\
\hline $\begin{array}{l}\text { LU2: Secure communication with } \\
\text { non-PGP and -S/MIME users }\end{array}$ & 1 & 5 & 5 & 1 & 5 & 5 & Best case: Yes \\
\hline LU3: Data Loss Prevention (DLP) & 1 & 5 & 1 & 1 & 1 & 1 & Best case: Yes \\
\hline LU4: Sending large files & 1 & 5 & 1 & 1 & 5 & 1 & Best case: Yes \\
\hline $\begin{array}{l}\text { LU5: Subsequent encryption of } \\
\text { incoming e-mail }\end{array}$ & 1 & 1 & 1 & 1 & 1 & 5 & Best case: Yes \\
\hline \multicolumn{8}{|l|}{ Low installation effort (IA) } \\
\hline $\begin{array}{l}\text { IA1: Creation of key pairs by the end } \\
\text { user }\end{array}$ & 1 & 5 & 1 & 1 & 5 & 1 & Best case: No \\
\hline $\begin{array}{l}\text { IA2: Certification of the public keys } \\
\text { for each end user, if necessary }\end{array}$ & 5 & 5 & 5 & 1 & 5 & 5 & Best case: No \\
\hline $\begin{array}{l}\text { IA3: Publishing of the public keys to } \\
\text { all communication partners by end } \\
\text { users }\end{array}$ & 1 & 3 & 1 & 1 & 3 & 3 & Best case: No \\
\hline $\begin{array}{l}\text { IA4: Collection of public keys from } \\
\text { all communication partners by end } \\
\text { users }\end{array}$ & 1 & 3 & 2 & 1 & 3 & 2 & Best case: No \\
\hline $\begin{array}{l}\text { IA5: Installation and configuration of } \\
\text { software on all client PCs, if } \\
\text { necessary }\end{array}$ & 1 & 5 & 1 & 1 & 5 & 1 & Best case: No \\
\hline $\begin{array}{l}\text { IA6: Installation and configuration of } \\
\text { central software, if necessary }\end{array}$ & 5 & 1 & 5 & 5 & 1 & 5 & Best case: No \\
\hline \multicolumn{8}{|l|}{ Low acquisition costs (AK) } \\
\hline AK1: One-time costs & 5 & 1 & 5 & 5 & 1 & 5 & Less is better. \\
\hline \multicolumn{8}{|l|}{ Low operating costs (BK) } \\
\hline BK1: Regular (monthly) costs & 5 & 5 & 4 & 5 & 5 & 3 & Less is better. \\
\hline \multicolumn{8}{|l|}{ Ease of operation (EB) } \\
\hline $\begin{array}{l}\text { EB1: Additional user actions required } \\
\text { when sending / receiving }\end{array}$ & 2 & 4 & 3 & 2 & 4 & 3 & Best case: No \\
\hline $\begin{array}{l}\text { EB2: Knowledge of encryption and } \\
\text { signing required }\end{array}$ & 3 & 5 & 3 & 2 & 5 & 3 & Best case: No \\
\hline \multicolumn{8}{|l|}{\begin{tabular}{|l|} 
Good support (SU) \\
\end{tabular}} \\
\hline $\begin{array}{l}\text { SU1: Help function on homepage, e. } \\
\text { g. FAQ, documentation, interactive e- } \\
\text { mail support }\end{array}$ & 4 & 3 & 3 & 5 & 3 & 4 & Best case: Yes \\
\hline SU2: Hotline & 1 & 5 & 1 & 1 & 5 & 1 & Best case: Yes \\
\hline SU3: On-site service & 1 & 5 & 1 & 1 & 5 & 1 & Best case: Yes \\
\hline \multicolumn{8}{|c|}{ High trustworthiness of the manufacturer/provider (HV) } \\
\hline $\begin{array}{l}\text { HV1: Data protection, legal } \\
\text { regulations in the country of origin }\end{array}$ & 5 & 5 & 4 & 5 & 4 & 5 & \\
\hline HV2: Awards & 1 & 4 & 1 & 1 & 1 & 5 & Better, the more awards. \\
\hline $\begin{array}{l}\text { HV3: Known vulnerabilities, } \\
\text { backdoors }\end{array}$ & 5 & 5 & 5 & 5 & 5 & 5 & Better, the less known security vulnerabilities. \\
\hline HV4: Source code viewable & 5 & 1 & 1 & 5 & 1 & 5 & Best case: Yes \\
\hline $\begin{array}{l}\text { HV5: Experience in the fields of } \\
\text { encryption, secure digital } \\
\text { communication, etc. }\end{array}$ & 2 & 5 & 4 & 4 & 5 & 4 & More experience is better. \\
\hline HV6: References & 4 & 5 & 1 & 1 & 5 & 1 & Many well-known customers are better. \\
\hline \multicolumn{8}{|l|}{ High system/product maturity (SR) } \\
\hline $\begin{array}{l}\text { SR1: Period since the first product } \\
\text { generation appeared }\end{array}$ & 2 & 4 & 2 & 4 & 5 & 4 & The longer, the better \\
\hline \multicolumn{8}{|l|}{ Good integrability (IB) } \\
\hline $\begin{array}{l}\text { IB1: Secure e-mail communication } \\
\text { from mobile devices possible }\end{array}$ & 3 & 1 & 1 & 1 & 1 & 1 & Best case: Yes \\
\hline $\begin{array}{l}\text { IB2: Availability/compatibility with } \\
\text { desktop operating systems }\end{array}$ & 4 & 5 & 4 & 3 & 5 & 4 & Better compatibility is better. \\
\hline $\begin{array}{l}\text { IB3: Compatibility with e-mail } \\
\text { clients }\end{array}$ & 2 & 5 & 2 & 3 & 5 & 2 & Better compatibility is better. \\
\hline
\end{tabular}




\section{Appendix 3: Calculation of the Total Benefits (Value Synthesis)}

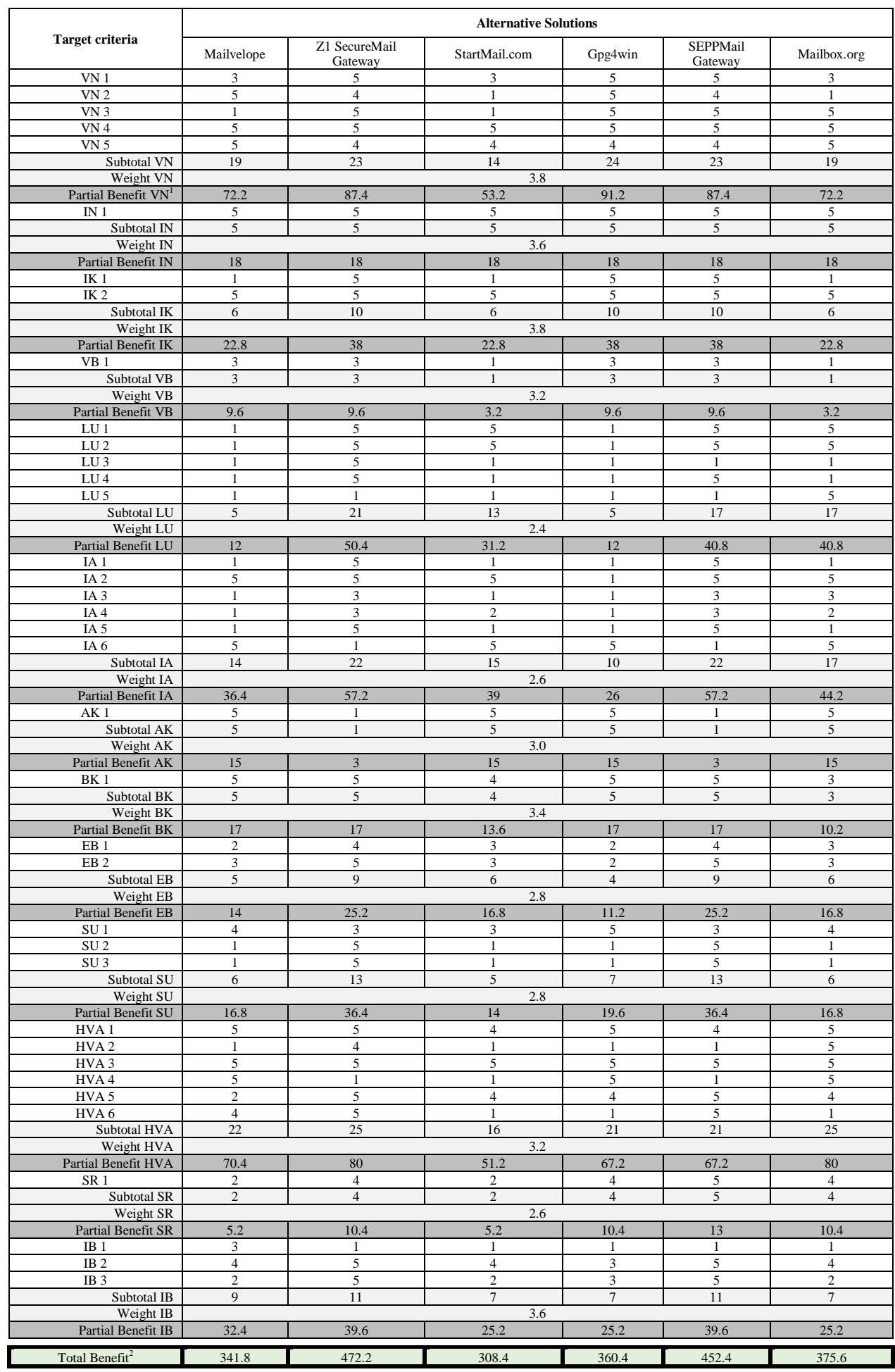

${ }^{1}$ The part benefit of a target is calculated by multiplying the weight with the sum of the target values ("subtotal").

2 The total benefit results from the addition of the partial benefits. The alternative is considered to be the "best" with the greatest overall benefit. 